\title{
PENERAPAN MANAJEMEN MUTU PADA USAHA GARMENT DI KECAMATAN PADEMANGAN TIMUR JAKARTA UTARA
}

\author{
Nur Hidayah $^{1}$, Yusbardini' ${ }^{2}$, Desy Nadhya Awiyah ${ }^{3}$ \\ ${ }^{1}$ Jurusan Manajemen ,FE Untar Jakarta \\ Email:nurh@fe.untar.ac.id \\ 2 Jurusan Manajemen FE Untar Jakarta \\ Email: yusbardini@fe.untar.ac.id \\ ${ }^{3}$ Jurusan Teknik Industri Universitas Brawijaya Malang \\ Email: drea.nadhya@yahoo.co.id
}

\begin{abstract}
ABSTRAK
Pengendalian kualitas/mutu sangat penting dalam memproduksi suatu barang untuk menjaga kestabilan mutu hasil produksi dan sebagai salah satu usaha untuk manemukan faktor-faktor terduga yang menyebabkan kurang lancarnya fungsi dalam proses suatu produksi sehingga bila terjadi gangguan dapat segera dilakukan tindakan pembetulan sebelum terlalu banyak produk yang tidak sesuai dengan produksi. Proses pengendalian produksi garment biasanya dilakukan dengan jalan melakukan pengecekan pada semua departemen guna meminimalisir cacat dalam produksi. Kegiatan PKM menerapkan manajemen mutu pada usaha Garment di Kecamatan pademgan timur- Jakarta utara penting dilakukan agar dapat memperkecil jumlah produk yang cacat, meningkatkan produksi dan meningkatkan dayasaing. Kegiatan PKM ini dilakukan pada usaha Garment yang bergerak di bidang pembuatan pakaian wanita dewasa yang berada di Pademanagan Timur Jakarta Utara. Kegiatan ini dilakukan dengan menggunakan metode wawancara, ceramah, sosialisasi atau praktek manajemen mutu dan dokumentasi. Hasil kegiatan PKM ini adalah mulai diterapkannya pengendalian mutu pada setiap kegiatan memproduksi pakaian dari mulai pengadaan bahan baku sampai dengan kegiatan finishing. Dengan diterapkanya manajemen mutu dan penendalian mutu pada setiap aktivitas produksi pada usaha garmen ini diharapkan dapat meminimalisir gangguan ataupun produk cacat sehingga produk yang dihasilkan dapat sesuai dengan permintaan konsumen.
\end{abstract}

Kata kunci :Manajemen mutu, kualitas produk, usaha garment

\section{PENDAHULUAN}

Pada Usaha Garmen kegiatan berproduksi merupakan suatu kegiatan yang cukup penting. Bahkan dalam berbagai macam pembicaraan, dikatakan bahwa produksi merupakan dapurnya perusahaan tersebut. Apabila pada kegiatan produksi terdapat berbagai macam hambatan dalam proses produksi, maka akan menimbulkan berbagai kerugian baik material maupun unmaterial. Sehingga diperlukan pengendalian kualitas dalam suatu perusahaan untuk meminimalisasi biaya operasional dalam produk, serta dapat memenuhi standar kualitas dari waktu yang telah ditentukan sebelumnya. Pengendalian kualitas/mutu sangat penting dalam memproduksi suatu barang untuk menjaga kestabilan mutu hasil produksi dan sebagai salah satu usaha untuk manemukan faktor-faktor terduga yang menyebabkan kurang lancarnya fungsi dalam proses suatu produksi sehingga bila terjadi gangguan dapat segera dilakukan tindakan pembetulan sebelum terlalu banyak produk yang tidak sesuai dengan produksi. Proses pengendalian produksi garment biasanya dilakukan dengan jalan melakukan pengecekan pada semua departemen guna meminimalisir cacat dalam produksi. .

Masalah jaminan mutu atau kualitas produk menjadi hal yang sangat penting, yaitu sebagai senjata utama untuk mencapai tujuan utama perusahaan, karena dengan kualitas produk yang baik akan meningkatkan kepuasan dan loyalitas konsumen. Dengan sendirinya akan berpengaruh 
terhadap keuntungan yang sesuai keinginan perusahaan. Untuk mencapai target produk dengan jaminan kualitas, pengawasan kualitas merupakan suatu kegiatan yang sangat perlu dilakukan dalam setiap kegiatan produksi karena kualitas barang atau jasa hasil produksi perusahaan itu merupakan cermin keberhasilan setiap perusahaan menurut pandangan masyarakat. Apabila mutu dari barang atau jasa yang dihasilkan itu buruk, dengan sendirinya konsumen akan langsung mengetahui bahwa perusahaan yang menghasilkan produk itu tidak baik pula. Tetapi mutu barang yang dihasilkan itu bagus, maka konsumen akan secara langsung memberikan nilai baik bagi perusahaan tersebut.

Usaha Garment yang terletak di Pademangan Timur merupakan usaha yang bergerak dibidang garment yang menghasilkan pakaian wanita dewasa, permintaan pasar terhadap produksi sangatlah besar sehingga usaha Garment harus selalu beusaha agar produksinya dapat ditingkatkan dengan kualitas sebagaimana yang diharapkan. Berproduksi berdasarkan order. Untuk dapat menghasilkan kualitas yang baik maka perlu adanya peningkatan dari berbagai hal misalnya, masalah yang menyangkut penyediaan penggunaan barang, pengurusan dan penempatan tenaga kerja, pemanfaatan saran dan prasarana produksi, serta penyempurnaan metode kerja yang baik. Jika hal tersebut dijalankan oleh usaha Garmen maka produk yang dihasilkan dapat selesai tepat pada waktunya dan kualitas sesuai dengan yang diharapkan. Bagi Garment hasil produksi dan kepuasan para konsumen menjadi kekuatan yang sangat penting untuk mencapai keberhasilan dalam merebut persaingan atau pangsa pasar. Perusahaan harus dapat meningkatkan mutu produknya sesuai dengan tuntutan buyer, hanya saja kebijakan yang diambil oleh Garment dalam memproduksi barang belum sepenuhnya memperhatikan mutu atau kualitas barang yang dihasilkan. Padahal faktor yang sangat pernting demi menjaga masa depan Garment adalah masalah kualitas maka perlu adanya suatu evaluasi terhadap proses dan hasil produk itu sendiri. Usaha Garmen harus memandang bahwa kualitas sebagai faktor kunci yang membawa keberhasilan, pengendalian kualitas merupakan jaminan produk perusahaan dengan tujuan produk yang dihasilkan memenuhi spesifikasi atau standart mutu yang telah ditetapkan oleh buyer maupun peusahaan. Hal ini perlu di terapkan melalui inspeksi secara periodik selama proses produksi berlangsung dan melakukan tindakan korektif pada hasil produksi sehingga dapat menekan jumlah produk yang rusak dan menjaga agar produk akhir sesuai dengan standar kulitas yang diinginkan buyer maupun perusahaan. Pengendalian kualitas juga dapat menghindari produk yang rusak ke tangan konsumen sehingga akan membuat nama baik perusahaan tetap terjaga. Dan dalam memenuhi keinginan buyer terhadap produk yang diinginkan perusahaan tidak akan mengalami kesulitan karena kualitas produk merupakan faktor dasar keputusan buyer dalam memilih dan menilai suatu produk.

Kegiatan PKM ini akan dilakukan pada periode januari sampai Juli 2018 pada usaha konveksi atau garmen dengan memberikan pengetahuan tentang pentingnya manajemen mutu pada usaha garment tersebut. Diharapkan dengan adanya pelatihan penerapan manajemen mutu ini usaha Garment lebih memperhatikan mutu produk yg dihasilkan. Dengan memperhatikan kondisi tersebut, melalui kegiatan PKM UNTAR sebagai akademisi mampu memberikan bekal pada usaha Garment di Kecamatan Pademangan timur Jakarta utara yang memiliki keterbatasan dalam manajemen mutu. Melalui pembekalan ini diharapkan usaha Garment dapat meningkatkan mutu usahanya lebih baik lagi dan dapat bersaing dengan usaha Garment lainnya

Permasalahan Mitra:

Usaha Garment di Kecamatan Pademangan Timur Jakarta Utara merupakan usaha Garment yang telah lama berdiri namun berkembangannya tidak begitu signifikan.Perusahaan telah melalukan pengendalian mutu namun masih terbatas. Hal ini menyebabkan hasil produksi 
kurang dimaksimalkan. Sehingga keuntungan pun belum maksimal. Faktor inilah yang perlu disikapi oleh tim PKM dalam membantu usaha garment dalam meningkatkan kualitas/ mutu produk agar dapat bersaing dengan usaha garment lain.

Permasalahan yang perlu diselesaikan adalah seperti yang dijelaskan dibawah ini.

a. Bagaimana Pengendalian mutu yang perlu diterapkan dalam kegiatan produksi pada usaha garment di Pademangan Timur agar output dari kegiatan produksinya dapat mencapai kualitas yang baik sesuai standar kualitas dan memenuhi kepuasan konsumen akan mutu produk yang dihasilkan.

b.Bagaimana tahapan pengendalian mutu yang perlu dilakukan usaha garment di Pademangan Timur agar dapat memperkecil tingkat kerusakan atau cacat dan agar produk akhir kualitasnya sesuai dengn tuntutan bayer.

\section{METODE PELAKSANAAN}

\section{A. Solusi Untuk Mengatasi Kemitraan}

Berdasarkan analisis situasi dan identifikasi masalah yang dihadapi pelaku usaha Garment, solusi penyelesaiannya adalah :

1. Melakukan kunjungan lapangan awal kepada usaha Garment yang terletak di kecamatan pademangan timur Jakarta Utara untuk mendalami situasi lapangan dan mendapatkan informasi tentang aktivitas produksi yang sedang dijalankan dalam menghasilkan produk pakaian wanita.

2. Melakukan kunjungan lapangan dalam rangka mendalami permasalahan manajemen mutu yang ada pada usaha Garmen.

3. Menyusun panduan untuk memberikan informasi tentang manajemen mutu yang perlu diterapkan dalam usaha Garment.

4. Menyusun buku panduan manajemen mutu usaha garment dan mensosialisasikannya kepada pengusaha garment untuk diterapkan dalam aktivitas berproduksi untuk menghasilkan produk yang berkualitas dan mengurang produk yang cacat. dapat dimanfaatkan dalam menghadapi persaingan bisnis Garment yang semakin tajam.

\section{B.Model yang Ditawarkan Untuk Mengatasi Masalah}

1. Model yang ditawarkan untuk mengatasi permasalahan pada kegiatan ini adalah : Menyusun modul manajemen mutu meliputi; teknik pengendalian mutu yang perlu diterapkan untuk semua tahapan dalam berproduksi dari mulai pengendalian bahan baku sampai dengan pengendalian pada saat produk akhir dihasilkan dan mensosialisasikan buku panduan mengenai manajemen mutu pada usaha garment,sehingga dapat peningkatan kualitas produk Garmen.

2. Memberikan pemahaman kepada pelaku usaha garment yang berada di kecamatan Pademangan Timur tentang perlu di terapkan pengendalian mutu melalui inspeksi secara periodik selama proses produksi berlangsung dan melakukan tindakan korektif pada hasil produksi sehingga dapat menekan jumlah produk yang rusak dan menjaga agar produk akhir sesuai dengan standar kulitas yang diinginkan buyer maupun perusahaan.

\section{HASIL DAN PEMBAHASAN}

1.Usaha Garment yang berlokasi di Pademangan Timur merupakan perusahaan garment, yang sudah berdiri cukup lama. Adapun tahapan aktivitas berproduksi pada perusahaan garmen ini adalah : 


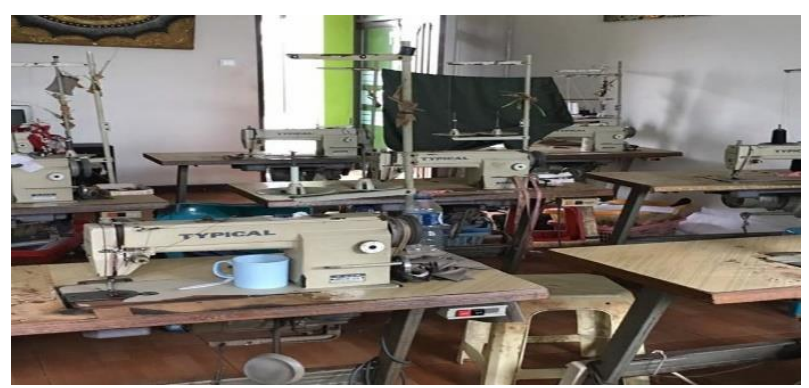

Gambar 1. Mesin Jahit usaha Garment dan setrika uap
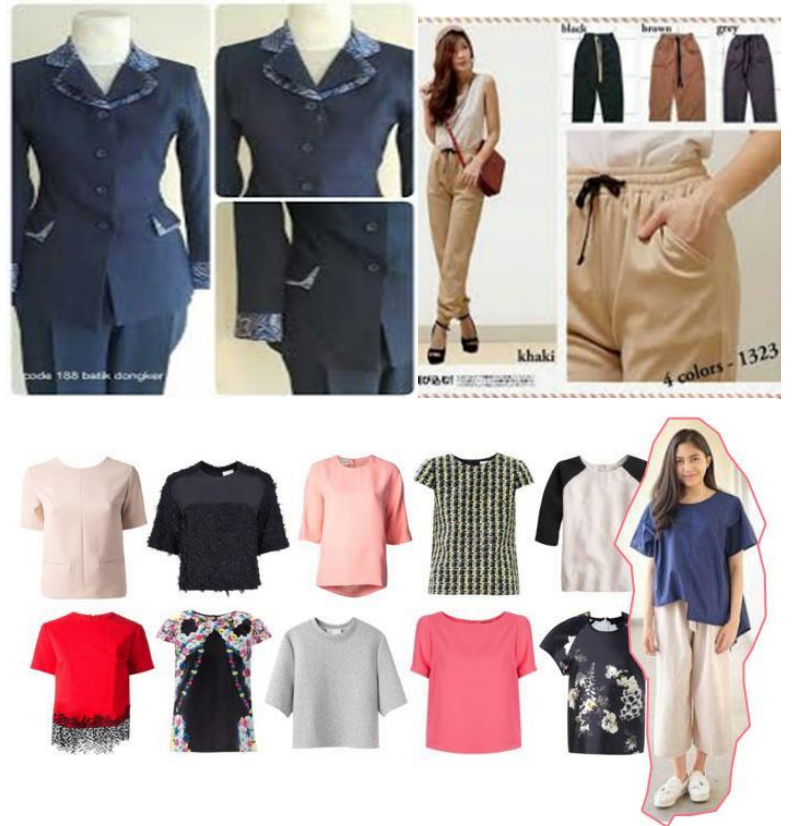

Gambar 2. Produk Garment

Secara singkat proses garmen dapat di gambarkan sebagai berikut:

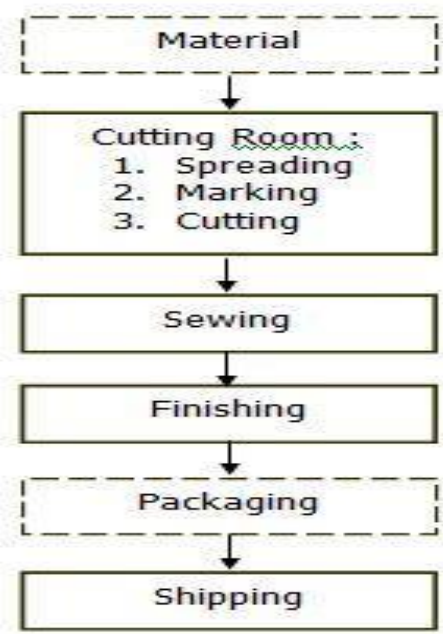

Alur Rroses Rembuatan Rakaian Sistema Garomen Manufacture

Gambar 3. Alur Pembuatan Pakaian Wanita pada Garment 
Proses pengendalian produksi garment di Pademangan Timur dilakukan dengan jalan melakukan pengecekan pada semua departemen guna meminimalisir cacat dalam produksi. Pengecekan yang dilakukan antara lain sebagi berikut :

1.Diadakannya cek material atau kain di departemen cutting untuk mengetahui cacat material, sebelum kain tersebut dipotong dalam bentuk komponen.

2.Setelah kain dipotong dalam bentuk komponen dilakukan cek kualitas potong dan ukuran komponen yang sebelumnya di mall atau digambar pola.

3.Cek jahit gabungan dari komponen yang sudah lolos seleksi menjadi pakaian setengah jadi. 4.Cek jahit gabungan komponen dan accesoris menjadi pakaian jadi total.

5.Cek barang jadi setelah di trimming atau dibatil dari sisa-sisa benang jahitnya. 6.Cek barang jadi setelah pakaian di Ironing atau digosok dengan setrika uap. 7.Cek barang jadi setelah masuk polybag dan packing.

Pada dasarnya faktor-faktor yang mempengaruhi proses pengendalian kualitas produksi garment di Pademangan Timur adalah :

a.Manusia

Sumber daya manusia adalah unsur utama yang menentukan dalam proses pengendalian kualitas yaitu tenaga kerja yang mempunyai komitmen, dedikasi, tanggung jawab, dan loyalitas yang tinggi yang sangat mempengaruhi dari kualitas produk yang dihasilkan. Ketelitian dari pengerjaan barang yang akan dihasilkan yang menentukan bagus tidaknya barang yang akan dihasilkan.

b. Mesin

Mesin sebagai alat pendukung pembuatan suatu produk memungkinkan berbagai variasi dalam bnetuk, jumlah dan kecepatan proses penyelesaian kerja. Pengaturan tata letak mesin-mesin produksi dilakukan untuk memperlancar proses produksi yang efektif dan efisien. Mesin dapat membantu mengurangi jumlah produk cacat yang diakibatkan oleh kelalaian tenaga kerja pada saat proses produksi. Faktor usia mesin merupakan salah satu penentu dari produk yang dihasilkan. Semakin tua mesin yang digunakan semakin banyak produk yang dihasilkan kurang dari kualitas standar. Selain faktor usia mesin terdapat ketepatan dan kecepatan dalam seting mesin yang sangat berpengaruh terhadap kualitas yang dihasilkan. Tingkat eror atau tingkat kerusakan mesin yang digunakan juga berpengaruh terhadap produk yang dihasilkan semakin banyak mesin yang rusak dalam memproduksi maka akan semakin banyak cacat yang terdapat dan akan memperlambat proses produksi.

c. Waktu

Faktor waktu dalam menentukan baik tidaknya produk yang dihasilkan sangat berpengaruh. Bila waktu pengerjaannya lama atau panjang bisa dipastikan kualitasnya akan semakin bagus. Bila waktunya sedikit atau mendesak maka proses produksi kurang teliti sehingga cacat yang dihasilkan kemungkinan banyak. Dalam memproduksi diusahakan karyawan usaha Garmen menghasilkan kualitas yang semaksimal mungkin walaupun waktunya sedikit.

2) Tahapan pengendalian mutu produk garment yang perlu dilakukan usaha Garmen.

Untuk memenuhi produk yang bermutu tinggi, maka di samping harus sesuai dengan standar yang diminta oleh konsumen (buyer), pembeli, pemakai atau pelanggan maka di sisi lain adalah faktor kepuasan pemakai. Kepuasan pemakai/pelanggan adalah menjadi perhatian dari mutu (quality) produk, karena selama produk tersebut diproses dan dalam kondisi di bawah proses pengendalian (control) maka selama produksi tersebut berjalan, produk tersebut telah sesuai dengan apa yang menjadi keinginan/harapan pelanggan (buyer).

Pada proses produksi garmen/pakaian di Pademangan Timur, setiap tahapan proses harus dilaksanakan pengendalian mutu dari pihak quality control, sehingga dapat memperkecil 
kemungkinan terjadinya produk cacat atau rusak yang selama ini menjadi permasalahan. Secara teknis, pengendalian mutu di industri garmen yang harus dilakukan atau di terapkan oleh usaha garmen di Pademangna Timur terdiri atas bagian-bagian berikut ini.

1. Quality Control (QC) pada Bahan Baku/Kain (Fabric)

Pengendalian mutu dilakukan untuk mengetahui/mengecek kualitas bahan baku (kain) yang akan diproses pada bagian pemotongan/cutting. Pengecekan pada bahan baku (kain) Tujuan dari pengendalian mutu pada bahan baku terutama kain adalah untuk mengetahui kualitas bahan yang berada dalam batas-batas toleransi yang diberikan pembeli atau pemesan (buyer), sebelum diproses menjadi produk massal.

2. Quality Control ( $Q C)$ pada Sample (Sample Inspection)

Sample merupakan contoh dari pihak pembeli (buyer) yang dibuat oleh perusahaan berdasarkan contoh dari pihak pembeli. Tujuan adanya pemeriksaan sample adalah agar seluruh sample yang dibuat oleh perusahaan bebas dari cacat, kerusakan, penyimpangan/ketidaksesuaian baik model, mutu jahitan/finishing, ukuran, warna, dan lain sebagainya. Mutu produk adalah kesesuaian ciri dan karakter produk yang dibuat, dengan ciri dan karakter produk yang diminta, dan kemampuan suatu produk untuk memenuhi kebutuhan pemakai dalam kondisi tertentu..

3. Quality Control $(Q C)$ pada Pemotongan/Cutting

Pengendalian mutu pada pemotongan meliputi :Gelaran kain,Arah benang (lusi/pakan), Konstruksi pola marker,Shedding,Toleransi ukuran, Hasil pemotongan/cutting

Adapun urutan prosedur pemeriksaan pada pemotongan adalah sebagai berikut :

- Periksa lembar kain bagian atas sampai pada lembar kain bagian bawah dengan posisi kertas marka.

- Periksa dan cocokkan komponen pola dengan komponen pola yang terdapat pada kertas marka (apakah komponen pola sudah lengkap atau belum). Petugas quality control harus mencatat semua temuan pada lembar laporan pemeriksaan.

- Periksa apakah terdapat kesalahan pemotongan pada setiap garis komponen pola ataukah tidak.

- Cek interlining dengan pola (apabila komponen garmen/pakaian menggunakan interlining dan bordir).

Kesalahan potong pada bagian yang seharusnya dipotong ulang pada kain cadangan, dilakukan pencatatan dan pemotongan ulang.

4. Quality Control $(Q C)$ pada Penjahitan/Sewing

Pengendalian mutu pada proses penjahitan meliputi :

Jumlah komponen pakaian

Jumlah setikan per inchi

Warna benang

Hasil jahitan (tidak mengkeret/puckering)

Aksesories

Mean label

Ukuran sesuai dengan standar (berdasarkan worksheet)

Adapun urutan prosedur pemeriksaan pada proses penjahitan adalah :

Bekerja sesuai dengan pedoman produksi (worksheet)

Mengikuti proses sesuai dengan layout

Periksa hasil pemotongan per komponen sesuai dengan sample dan toleransi

Memeriksa jumlah setikan dalam 1 inchi (stitch/inchi) 
Periksa hasil jahitan dan ukuran tiap tahapan proses

Periksa hasil jadi sesuai dengan worksheet

Periksa hasil jadi setelah dilakukan trimming

Semua data dicatat pada blangko yang sudah disediakan

5. Quality Control ( $Q C)$ pada finishing

Pengendalian mutu pada proses finishing meliputi :

Seterika/ironing

Pengecekan hasil pakaian setelah diseterika

Pengelompokkan pakaian

Packing sesuai dengan worksheet

Adapun urutan prosedur pemeriksaan pada proses finishing adalah :

Terima pakaian jadi dari bagian penjahitan/sewing

Cek style, jahitan dan ukuran

Cek hasil seterika (apabila ditemukan cacat maka pakaian ditransfer ke bagian packing untuk diperbaiki).

Memisahkan antara cacat minor dan cacat mayor

Mencatat hasil cacat minor dan cacat mayor untuk dimasukkan pada Grade, untuk kemudian dipertanggungjawabkan jumlah pakaian yang diterima, untuk diketahui oleh pimpinan.

Cek packing sesuai dengan worksheet

\section{Quality Control akhir (Final Inspection)}

Pengendalian mutu akhir dilakukan dengan cara membongkar beberapa karton/box dan mengambil beberapa pakaian yang sudah di polybag atau dikemas untuk dicek bagianbagian kualitas mutu produk tersebut. Pengecekan akhir meliputi :

Styling atau penampilan pakaian

Jahitan dan ukuran

Measurement atau mengukur pakaian

Memberi catatan atau komentar sesuai standar yang ditetapkan (worksheet) pada blangko yang telah disiapkan

Tujuan pengendalian mutu akhir

Bagian quality control dapat mengevaluasi hasil pekerjaan secara keseluruhan.

Memberikan informasi/catatan/record kepada manajemen yang berkaitan dengan mutu garmen yang akan dikirim kepada pihak pembeli/buyer.

Kesempatan terakhir bagi manajemen untuk menemukan masalah sebelum barang dikirim ke pihak pembeli.

Manfaat pengendalian mutu akhir:

Mengetahui tindakan seperlunya atas suatu produk garmen yang diterima atau ditolak pihak pembeli, sehingga produk tersebut dapat diterima secara baik oleh pembeli/buyer.

Mengetahui profesionalisme dan kinerja manajemen perusahaan.

Sistem Pemeriksaan Akhir (Final Inspections)

Sistem pemeriksaan akhir dilakukan pada :

(1) Karton pertama pengepakan (garment packaging)

(2) $25 \%$ karton garmen selesai di-packaging 
(3) $75 \%$ karton garmen belum selesai di-packaging

Standar pemeriksaan mutu mengikuti acceptable quality level (AQL), yang berarti mutu kualitas yang dapat diterima oleh pembeli.

\section{KESIMPULAN DAN SARAN}

Kesimpulan.

1. Pengendalian kualitas mutu yang perlu dilakukan oleh usaha garment di Pademangan Timur sudah baik yaitu dengan melalukan pengecekan pada setiap aktifitas, hanya saja perlu menjadi perhatian usaha garment dalam menghasilkan produk berkualitas ada tiga hal yang perlu diperhatikan yaitu menusia, mesin dan waktu. Hal ini perlu diperhatikan dalam memproduksi suatu barang untuk menjaga kestabilan mutu hasil produksi.

2. Pengendalian kualitas yang perlu di terapkan pada usaha Garmen di Pademangan timur adalah pengendalian (countrol) yang dilakukan oleh pihak quality control, pada setiap kegiatan produksi seperti : Quality Control $(Q C)$ pada Bahan Baku/Kain (Fabric)sampai dengan Quality Control akhir (Final Inspection) untuk menjaga kestabilan mutu hasil produksi dan sebagai salah satu usaha untuk menemukan faktor-faktor terduga yang menyebabkan kurang lancarnya fungsi dalam proses suatu produksi sehingga bila terjadi gangguan dapat segera dilakukan tindakan pembetulan sebelum terlalu banyak produk Saran yang tidak sesuai dengan produksi.

Dalam produksi garment disarankan sebagai berikut.

1. Pengendalian yang baik adalah pengendalian mutu yang dilakukan secara bertahap dari mulai bahan baku sampai dengan finishing, serta dilakukan pengendalian keseluruhan atau pengendalian akhir sehingga dapat menghasilhan produk yang mutu kualitasnya dapat diterima oleh pembeli.Diharapkan usaha Garment memperhatikannya.

2. Hendaknya lebih menekankan kepada karyawan untuk dapat memperhatikan kebersihan lingkungan dan alat yang digunakan terutama pada mesin jahit yang digunakan supaya pelumas mesin dan debu atau tanah, tidak banyak mengotori kain yang digunakan.

3. Penyebab-penyebab ketidaksesuaian pada proses produksi garment dapat diantisipasi dengan cara memperketat seleksi karyawan yang bekerja sesuai dengan keahliaan dan memberikan pengarahan pada karyawan terutama pada operator mesin jahit agar lebih memperhatikan dan berhati-hati.

\section{Ucapan Terima Kasih}

Ucapan terimakasih kami sampai kepada pihak-pihak utama yang mendukung penelitian ini, yaitu DPPM sebagai pemberi dana dan Dekan FE Untar dan pihak pihak lain yang tidak dapat kami sebutkan satu persatu.

\section{Referensi}

Ahyari, Agus. 2002. Manajemen Pengendalian Produksi. Yogyakarta : BPFE

Andi. Prawirosentono, Suyadi. 2002. Manajemen Mutu Terpadu. Edisi 1. Jakarta : Bumi Aks

Dorothea, Wahyu, Ariani. 2004. Pengendalian Kualitas. Yogyakarta :BPFE

Handoko, T. Hani. 1984. Dasar - dasar Manajemen Produksi dan Operasi. Yogyakarta : BPFE - Yogyakarta.

Render, dan Heizer. 2004. Manajemen Operasi (terjemahan). Edisi 7, Jakarta : Salamba Empat

Yamit, Zulian. 2002. Manajemen Produksi dan Operasi. Ekonomi FE UII : Yogyakarta 